\author{
PIOTR WOJDAK \\ Uniwersytet Szczeciński
}

\title{
CZYM JEST I DOKĄD SIĘGA RODZAJ (NIE)NATURALNY?
}

[...] ktoś w starożytności dla sprawy rodzaju użył słów „rodzaj męski” (arseniká, masculina) i żeński (thelyká, feminina) [...] Te terminy, seksualizujące gramatyki szkolne przez dwa tysiąclecia, tak się ludziom wbiły głowę, że pewien cenzor w XIX wieku skreślił zwrot naga prawda jako nieprzyzwoity, bo prawdzie będącej przecież rodzaju żeńskiego nie przystoi być nagą. (Tokarski 1967: 71-72)

Pojęcie rodzaju naturalnego jest kluczowe dla problematyki wyrażania płci w języku - głównie w ramach opisu wielowymiarowej (prymarnie syntaktycznej) kategorii rodzaju gramatycznego rzeczownika, ale nie tylko. Zwykle przyznaje mu się bowiem mniejszą lub większą autonomię wobec pojęcia rodzaju gramatycznego.

Sam termin jest w polskiej literaturze językoznawczej często stosowany, lecz rzadko objaśniany. Można z grubsza ustalać grupę rzeczowników, które mają rodzaj naturalny, i podawać konkretne ich przykłady, a jednocześnie nie eksplikować istoty pojęcia. Od braku definicji bardziej jeszcze dokuczliwe są niejasne przedstawienia relacji między rodzajem naturalnym i gramatycznym (spotykane głównie jednak w starszej literaturze).

Podejmujemy próbę uporządkowania problematyki rodzaju naturalnego. Dzielimy się rozważaniami na temat istoty (punkt 1.) i zakresu pojęcia (punkt 2.). W opozycji do szerokiego rozumienia terminu proponujemy stosowanie dodatkowego przeciwstawnego pojęcia rodzaju (także podrodzaju) nienaturalnego (punkt 3.). Szeroko - od strony semantycznej lub nawet pragmatycznej - ujmowany rodzaj naturalny traci bowiem na swej ,naturalności” z perspektywy gramatycznej. Nawias użyty w tytule ma zwrócić uwagę na tę dialektykę terminu rodzaj naturalny.

\section{Istota rodzaju naturalnego}

W najwęższym ujęciu rodzaj naturalny przysługuje masculinom o znaczeniu męskim i femininom o znaczeniu żeńskim.

W wypadku zgodności cechy semantycznej desygnatu i rodzaju gramatycznego mówi się o rodzaju naturalnym (Saloni w EJO: 497).

O takich rzeczownikach, w których występuje korelacja przynależności do podzbioru nazywanego odpowiednim rodzajem i cechy semantycznej, która stanowi nazwę danej klasy, mówi się, że mają rodzaj naturalny. Rodzaj naturalny miałby w języku polskim np. rzeczownik chłop czy 
baba, nie miałby go natomiast rzeczownik babsztyl, który jest rodzaju męskiego (bo ten głupi babsztyl byt), choć może się odnosić tylko do osoby płci żeńskiej (Saloni 1976: 50).

Tak rozumiane rodzaje naturalne ${ }^{1}$ - nazwijmy ten sposób rozumienia zgodnościowym - nie istnieją bez odpowiedniego znaczącego nazewnictwa rodzajów gramatycznych, bez dwóch co najmniej klasycznych etykiet: „męski” i „,̇eński”, które kierują uwagę nie tylko ku semantycznym prototypom rodzajów (ich częściowemu tylko, a i tak niepozbawionemu wyjątków umocowaniu w płci nazywanych obiektów), lecz także ku - owianej „megadiachroniczną” tajemnicą - genezie szerokiego zakresu gramatycznej „męskości” i „żeńskości”". Tymczasem gramatyka opisowa z zasady jest obojętna (,agnostyczna”) wobec rozwoju i - tym bardziej - pochodzenia kategorii gramatycznych. W rozumieniu rodzaju naturalnego dochodzi więc do swoistej ucieczki „w bok i w przód” - tzn. do odgramatykalizowania pojęcia i zarazem do jego rozszerzania (zob. punkt 2.) ${ }^{3}$. W konsekwencji określenie „naturalny” wcale nie przesądza gramatyczno-semantycznej „zgodności”; zwykle wskazuje na samą tylko płaszczyznę znaczenia. Co więcej, rodzaj naturalny służy gdzieniegdzie za hasło wywoławcze dla całego kompleksowego zagadnienia wyrażania płci w języku - za pomocą różnych środków, nie tylko za pomocą rodzaju gramatycznego (por. Mączyński 1981, Stefańczyk 2007, komentowani dalej).

Odpowiadając na pytanie, czym jest rodzaj naturalny, nawet zwolennicy wąskiego rozumienia terminu zapewne nie wyrażą się, że jest określoną zgodnością czy korelacją; „fałsz” takiej kategoryzacji polegałby, jak się wydaje, na rozbieżności poziomów abstrakcji. Odpowiedniejsza jest mniej abstrakcyjna kategoria nadrzędna (genus proximum, hiperonim) - w grę wchodzi jeden z dwóch partycypantów owej zgodności czy korelacji. Oznacza to, że klasyczne definicje rodzaju naturalnego - per genus proximum et differentiam specificam - będą „,stronnicze”, przy czym z przeglądu polonistycznej literatury językoznawczej wynika, że w zasadzie realizowany jest tylko jeden typ owej stronniczości, mianowicie rodzaj naturalny kategoryzowany jest niegramatycznie: jako cecha semantyczna względnie referencjalna (czasem konkretnie jako płeć), a nie jako rodzaj gramatyczny ${ }^{4}$.

${ }^{1}$ Opozycja rodzaj naturalny - rodzaje naturalne odznacza się komplikacją analogiczną do opozycji: rodzaj gramatyczny - rodzaje gramatyczne. Dochodzi tu mianowicie do częściowej neutralizacji znaczeniowej. Od czysto formalnej opozycji liczb istotniejsze jest bowiem rozróżnienie znaczeń typu: 'kategoria' - 'wartość tej kategorii'. Formy liczby mnogiej mogą występować w pierwszym znaczeniu, ale - jak się wydaje - nadają mu wówczas dodatkowy profil: 'kategoria, na którą składają się różne wartości'. W ten sposób można uzasadniać dość swobodny - także w tym artykule - dobór form singularnych i pluralnych terminu.

${ }^{2}$ Starsze gramatyki z kręgu indoeuropejskiego, począwszy od niemieckiej gramatyki Grimma, w rodzajach rzeczowników doszukiwały się jakiejś pierwotnej animizującej klasyfikacji przedmiotów. Por. Jan Tokarski (1967: 72), który podaje przykład - cytowanej dalej - gramatyki Stanisława Szobera (1953: 119-120).

Inną sprawą jest wtórna semantyzacja (,naturalizacja”) rodzajów gramatycznych, ich podatność na przyjmowanie treści naddanych, symbolicznych. Jak pisze Maria Renata Mayenowa (1974: 168), „klasyfikacja rodzajowa jest $[\ldots]$ naturalną podstawą wyznaczającą kierunki metaforyzacji i ograniczającą jej możliwości” (za Nowosad-Bakalarczyk 2009: 168), m.in. w odniesieniu do rzeczowników oznaczających w poszczególnych językach śmierć, ojczyznę, słońce, księżyc czy różne gatunki drzew.

${ }^{3}$ Zdajemy sobie sprawę, że jest to ahistoryczne spojrzenie na genezę określonego (dominującego) sposobu rozumienia rodzaju naturalnego.

${ }^{4}$ Por. (prace wymienione w kolejności chronologicznej): Klemensiewicz 1986 [1952]: 51; Reczek 1975: 61; Rothstein 1976: 247; Mączyński 1981: 239 i in.; Bańczerowski, Pogonowski, Zgółka 1982: 217; Bąk 1984: 162; Strutyński 1997: 162; Karpowicz 1999: 70; Laskowski 1998: 208; EJP 1999: 322; Wróbel 2001: 91; Słownik 
Inna sprawa, że objaśnienia na ogół odznaczają się lapidarnością i niedostatkiem eksplicytności (samo utożsamianie rodzaju naturalnego z płcią - jeśli nie zaznacza się językowego statusu owej płci - budzi logiczne zastrzeżenia). Nie wiadomo, na ile wynika to z niedostrzegania problemu, a na ile z merytorycznych wątpliwości prowadzących do świadomych niedopowiedzeń. Wzmianki o wskazywaniu na płeć desygnatu czy jej sygnalizowaniu 5 same w sobie mogą pasować zarówno do wąskiej orientacji gramatycznej (czyli że w istocie chodziłoby o rodzaj gramatyczny, który (trafnie) wskazuje na płeć desygnatu), jak i do szerokiej orientacji „oderwanej” od rodzaju gramatycznego. Z kontekstu okazuje się jednak, że autorzy nie mają na myśli tej pierwszej orientacji.

Niedopowiedzenia same w sobie nie są jeszcze rażące, rażące są objaśnienia wewnętrznie sprzeczne. $Z$ wyjątkowo pokrętną prezentacją rodzaju naturalnego, a przy okazji i rodzaju gramatycznego, można się spotkać w gramatyce Stanisława Szobera (1953); wynika z niej bowiem, że rodzaj naturalny jest i zarazem nie jest rodzajem gramatycznym oraz że większość rzeczowników osobowych i niektóre inne żywotne mają rodzaj gramatyczny i zarazem go nie mają (mają tylko naturalny) ${ }^{6}$. Rodzi się więc wątpliwość, czy rodzaj gramatyczny jest dla rzeczowników kategorią powszechną; ponadto jako istotę tej kategorii (podstawę rozróżniania jej wartości) najpierw - trafnie - uznaje autor łączliwość z przymiotnikami (choć wtedy akurat używa terminu rodzaj bez żadnej przydawki), a dalej błędnie - końcówki fleksyjne. Osobliwej „morfologizacji” (a zarazem desemantyzacji) poddaje też - choć znów niekonsekwentnie (w sposób niejawnie alternatywny) - rodzaj naturalny, uznaje bowiem niezgodność rodzaju naturalnego z rodzajem gramatycznym takich rzeczowników, jak KSIĄŻE, POETA, (ten) SĘDZIA (chodzi tu więc o relację między morfologią z jednej a składnią i semantyką z drugiej strony) ${ }^{7}$. Dwa akapity wcześniej rodzaj naturalny przedstawiany był wprawdzie „normalnie” (,wskazuje (...) na płeć naturalną”), ale wśród przykładów pojawiło się m.in. wyrażenie z rzeczownikiem (uczciwy rzemieśl$n i k)$, który nie jest nazwą wyłącznie męską ${ }^{8}$ Inne podobnie nieklarowne przykłady (uczci-

gramatyki 2002: 214; Język polski. Kompendium 2005: 753; Brzozowska 2005: 36-37; Kowalikowa 2005: 61; Płóciennik, Podlaska 2007: 229; Stefańczyk 2007: 21-22; Nowosad-Bakalarczyk 2009: 18-21, Grochola-Szczepanek 2010; Polański, Nowak 2011: 208; Batko-Tokarz 2013: 71.

5 Por. np. Szober (1953: 118): „Rodzaj rzeczowników żywotnych, tj. rzeczowników oznaczających ludzi i zwierzęta, nazywa się rodzajem naturalnym, wskazuje bowiem na płeć naturalną oznaczanego przez rzeczownik osobnika ludzkiego lub zwierzęcego”; Mączyński (1981: 235): „Funkcją rodzaju naturalnego, jak wiadomo, jest wskazywanie na płeć desygnatu”; Polański, Nowak (2011: 208): „rodzaj naturalny sygnalizuje płeć istot żywych, por. rzeczowniki osobowe, np. (ten) chłopiec : (ta) dziewczyna i żywotne: (ten) byk - (ta) krowa".

${ }^{6}$ Oczywiście, istnieją różne koncepcje i rodzaju naturalnego, i rodzaju gramatycznego i można je kolejno referować i porównywać, nawet nie będąc zdecydowanym co do ich ewaluacji, ale ujęć wobec siebie sprzecznych nie wolno ,spiętrzać” bez cienia krytycznego (auto)dystansu.

7 Więcej sensu od sprowadzania rodzaju naturalnego do ,rodzaju morfologicznego” miałoby ustanowienie dodatkowego pojęcia rodzaju naturalnego pod względem morfologicznym. Byłby to rodzaj gramatyczny o typowych wykładnikach morfologicznych, o typowym wzorze deklinacyjnym (czy w duchu S. Szobera: o sobie właściwych zakończeniach).

${ }^{8}$ Brakuje tu więc wrażliwości na rozróżnianie semantyki (ogólnej potencji znaczeniowej) i pragmatyki (konkretyzowanego odniesienia/referencji) (na ten temat zob. również uwagę w przypisie 15.). Zapewne dają też znać o sobie zmiany realnoznaczeniowe na przestrzeni ostatniego wieku: kiedyś zawody rzemieślnicze rzadziej wykonywały kobiety (a może wcale ich nie wykonywały?). 
wy człowiek, wierny pies) podane zostały dalej a propos morfologicznej również naturalności rodzaju.

Oto cały komentowany ustęp z gramatyki S. Szobera.

Zdolność rzeczowników wpływania na formę łączących się z nimi przymiotników nazywa się ich rodzajem [...].

Rodzaj rzeczowników żywotnych, tj. rzeczowników oznaczających ludzi i zwierzęta, nazywa się rodzajem naturalnym, wskazuje bowiem na płeć naturalną oznaczanego przez rzeczownik osobnika ludzkiego lub zwierzęcego, np. uczciwy rzemieślnik, pracowita kobieta, silny wól, rącza klacz. Rodzaj natomiast rzeczowników nieżywotnych oznaczających rośliny i przedmioty martwe przechowuje się w języku tylko dzięki ustalonemu zwyczajowi, dlatego też nazywa się rodzajem gramatycznym, np. duży ogród, twardy kamień, wielki piec; długa deska, wartka rzeka, ciemna noc, obszerna sień; wygodne krzesło, szerokie pole [...].

Rzeczowniki nieżywotne mają tylko rodzaj gramatyczny. Co się zaś tyczy rzeczowników żywotnych, to takie przykłady, jak uczciwy czlowiek, dobry chłopiec, wierny pies; troskliwa matka, przywiązana córka, wskazują, że mają one w większości wypadków nie tylko rodzaj naturalny, lecz i gramatyczny, większość bowiem rzeczowników oznaczających ludzi i zwierzęta płci męskiej ma zakończenia właściwe męskiemu rodzajowi gramatycznemu, a rzeczowniki oznaczające ludzi i zwierzęta płci żeńskiej mają przeważnie końcówki właściwe żeńskiemu rodzajowi gramatycznemu.

Bywają jednak wypadki, kiedy rodzaj naturalny rzeczowników żywotnych nie zgadza się z ich rodzajem gramatycznym; mówimy np. stary książe, wielki poeta, sprawiedliwy sędzia, chociaż pierwszy z tych rzeczowników na podstawie zakończenia powinien mieć rodzaj nijaki, a dwa następne - rodzaj żeński.

Na ogół jednak biorąc, w rzeczownikach polskich przeważa rodzaj gramatyczny, mają go bowiem nie tylko rzeczowniki nieżywotne, lecz również większość [sic!] rzeczowników żywotnych. (Szober 1953: 118-119)

Fałszywy obraz relacji między rodzajem gramatycznym i rodzajem naturalnym wyłania się także z pracy Jana Tokarskiego (1967). Podobnie jak u S. Szobera (zob. drugi z przytoczonych wyżej akapitów, pierwszy pełny) nad rodzajem gramatycznym i rodzajem naturalnym zdaje się tam istnieć jakiś rodzaj po prostu, rodzaj bez kategoryzującej przydawki.

Tradycyjna gramatyka, dostrzegając przygodność rodzaju w większości wyrazów, ucieka się do odróżnienia rodzaju naturalnego, gdy jest on zgodny z płcią istot przez wyrazy te oznaczanych i rodzaju gramatycznego, gdy się on odnosi do rzeczy nie mających z płcią nic wspólnego lub oznaczonych sprzecznie z ich płcią (Tokarski 1967: 72).

Wystarczy odrobina niedobrej woli (niedobrej, bo zapewne niezgodnej z intencją autora), by na podstawie cytowanego ustępu wnioskować, że dany rzeczownik albo ma rodzaj naturalny, albo gramatyczny, że oba „rodzaje” się wykluczają. Nawet jednak i bez tej złej woli trzeba krytycznie odnieść się do stawiania w jednym szeregu rzeczy o diametralnie różnym stopniu (i - nomen omen - rodzaju) kategorialności albo - przy innym (niestety rzadszym czy mniej prawdopodobnym) rozumieniu - takich, które pozostają ze sobą w relacji hiponimii: rodzaj gramatyczny - jako hiperonim, rodzaj naturalny - jako hiponim .

${ }^{9}$ Skoro przywołaliśmy klasyków, zauważmy jeszcze, że w porównaniu do Szobera i Tokarskiego klarownie - choć bardzo lakonicznie - wypowiada się w swojej gramatyce na interesujący nas temat Zenon Klemensiewcz (1986: 51): „Rodzaj rzeczowników osobowych związany jest z rodzajem naturalnym, czyli płcią nazwanych 
Także niestety w nowej literaturze pokutuje jeszcze tradycja „lekkomyślnych” partnerskich zestawień rodzaju gramatycznego i rodzaju naturalnego rzeczowników (za daleko idącego „upodmiotowiania” tego drugiego), sprowadzania ich (czyżby na wzór cytowanych klasyków?) do jakiegoś zagadkowego wspólnego mianownika, do (kategorii!) rodzaju ,bezprzydawkowego”.

Kategoria rodzaju pełni dwie funkcje: tekstową (prymarnie) i nominatywną (sekundarnie). Po pierwsze, rodzaj gramatyczny informuje o związkach składniowych między częściami zdania. Po drugie, rodzaj naturalny sygnalizuje płeć istot żywych, por. rzeczowniki osobowe, np. (ten) chtopiec : (ta) dziewczyna i żywotne: (ten) byk - (ta) krowa. (Polański, Nowak 2011: 207-208).

Przywołany fragment łatwo poprawić (uznając jednak, zapewne wbrew intencji autorów, że rodzaj naturalny jest określonym typem rodzaju gramatycznego):

Kategoria rodzaju gramatycznego pełni dwie funkcje: tekstową (prymarnie) i nominatywną (sekundarnie). Po pierwsze, informuje o związkach składniowych miedzy częściami zdania. Po drugie, sygnalizuje płeć istot żywych (wtedy mówi się o rodzaju naturalnym), por. rzeczowniki osobowe, np. (ten) chłopiec : (ta) dziewczyna i żywotne: (ten) byk-(ta) krowa. (Polański, Nowak 2011: 207-208).

W obliczu niejasności czy sprzeczności wokół popularnego terminu nie dziwi praktyka przywoływania go z dystansem sygnalizowanym przez cudzysłów (Przepiórkowski i in. 2002: 123) lub wyrażenie „tzw.” (Rothstein 1976: 247). W ten sposób rodzaj naturalny staje się tylko niepodlegającym definiowaniu hasłem wywoławczym dla określonego przedmiotu badań (inna sprawa, czy wtedy ów przedmiot rzeczywiście jest określony).

W fachowej literaturze znajdziemy i takie prezentacje kategorii rodzaju rzeczownika, które z powodzeniem obywają się bez pojęcia rodzaju naturalnego (Bańko 2002: 150-153, Nagórko 1997: 94, Nauka o języku dla polonistów, s. 198-200). Chcemy je traktować jako przejaw sceptycyzmu wobec niedookreślonego terminu, który w głównym nurcie interpretacji emancypowany jest wobec rodzaju gramatycznego (jako cecha semantyczna).

Zarzucenia terminu nie można jednak pochwalić, gdy dotyczy językoznawczych encyklopedii czy słowników. Po tego typu źródłach spodziewamy się przecież klasycznych definicji. W EJP i EJO rodzaj naturalny jest jedynie wzmiankowany pod hasłem rodzaj gramatyczny; w starszym STJ nie pojawia się wcale (inna sprawa, że ten niezbyt obszerny słownik ogólnie charakteryzuje się lapidarnością artykułów hasłowych).

Pozytywnie wyróżnia się Słownik gramatyki języka polskiego pod redakcją Włodzimierza Gruszczyńskiego i Jerzego Bralczyka (2002). Znajduje się w nim hasło rodzaj naturalny z ciekawą definicją, bo o niegramatycznym punkcie wyjścia, ale wąską:

płeć istoty nazywanej przez dany rzeczownik, mająca wpływ na rodzaj gramatyczny w niektórych klasach rzeczowników ${ }^{10}$ (s. 214).

przez nie osób". Tu przynajmniej nie ma wątpliwości, że rodzaj naturalny nie stanowi - w zakresie rzeczowników żywotnych - jakiejś alternatywy wobec rodzaju gramatycznego, lecz jest cechą semantyczną.

${ }^{10} \mathrm{Z}$ synchronicznej perspektywy opisu języka twierdzenia co do zależności przyczynowo-skutkowych między płcią a rodzajem są nieweryfikowalne. Dlatego od ,mająca wpływ na rodzaj gramatyczny” bezpieczniejsze byłyby sformułowania typu: „znajdująca odzwierciedlenie w rodzaju gramatycznym”, „pokrywająca się z rodzajem gramatycznym" itp. 
W monografii poświęconej wielorodzajowości (Wojdak 2013) piszący te słowa przedstawił dwie alternatywne definicje rodzaju naturalnego: węższą, wychodzącą od rodzaju gramatycznego, i szerszą, wychodzącą od cechy semantycznej. O możliwych wartościach szeroko (semantycznie) rozumianego rodzaju naturalnego, niepokrywających się z rodzajami właściwymi (gramatycznymi), wspominał - nawiązując do opracowania Daniela Weissa (1993) jeszcze wcześniej (Wojdak 2005). Nie zdawał sobie wtedy sprawy z ,absolutyzmu” semantycznej koncepcji rodzaju naturalnego; może zmyliło go wyżej cytowane - nie gramatyczne wprawdzie, ale też nie semantyczne (neutralne) i z całą pewnością wąskie („zgodnościowe”) - rozumienie rodzaju naturalnego Zygmunta Saloniego (,jeśli wpływowy Saloni tak definiuje, to pewnie inni podobnie"). Miał nietrafną intuicję, że obie koncepcje - gramatyczna i semantyczna (nie uświadamiał sobie jeszcze możliwości spojrzenia pragmatycznego) współegzystują w pewnej równowadze i wzajemnym ,poszanowaniu”"11, za którymi przemawia ich komplementarność (rozumienie węższe - rozumienie szersze). Teraz uznaje potrzebę „dowartościowania” tej - oględnie mówiąc - niedominującej koncepcji gramatycznej i popiera stosowanie dobitnego terminu: naturalny rodzaj gramatyczny ${ }^{12}$.

Niegramatyczny (semantyczny czy ewentualnie nawet pragmatyczny) punkt wyjścia czyni pojęcie rodzaju naturalnego bardziej podatnym na rozszerzenie. W rozszerzeniu tym jest jakaś naturalna - nomen omen - dążność do uogólnienia, uwolnienia się od nomenklaturowej relatywności wobec rodzajów gramatycznych ${ }^{13}$. Trudno jednak sobie wyobrazić, aby owo rozszerzanie mogło zajść na tyle daleko, by rodzaj naturalny zyskał walor powszechności i stał się równym partnerem dla rodzaju gramatycznego. W odniesieniu do nazw obiektów pozbawionych płci nie należy więc (przynajmniej przy obecnym stanie badań) pisać, że rodzaj gramatyczny nie pokrywa się z rodzajem naturalnym (bo tego drugiego po prostu tam nie ma $)^{14}$.

${ }^{11}$ Nie chcemy przez to powiedzieć, że koncepcja gramatyczna była krytykowana. Nie wiemy, czy w ogóle była dyskutowana.

${ }^{12}$ Nasuwa się tu analogia do terminów z zakresu tradycyjnej składni zdania pojedynczego. Istnieje w niej - jak wiadomo - przeciwstawienie podmiotu w mianowniku i podmiotu inaczej wyrażonego: dopełniaczem (czy nawet innym przypadkiem zależnym) lub bezokolicznikiem. Pierwszy z nich bywa nazywany podmiotem gramatycznym, drugi - logicznym. $\mathrm{W}$ istocie jednak podmiot $\mathrm{w}$ mianowniku zwykle rozumiany jest jako równocześnie gramatyczny i logiczny i wtedy nazwa jednoczłonowa ma charakter skrótowy; nazwę dwuczłonową proponuje Irmina Judycka i inni (1971: 224-225).

Podobnie nieprecyzyjny jest termin orzeczenie imienne - używany zamiast „orzeczenia słowno-imiennego” w odniesieniu do orzeczenia złożonego składającego się z członu werbalnego (łącznika) i członu podlegającego deklinacji (orzecznika).

${ }^{13} \mathrm{~W}$ kontekście tych aspiracji rodzaje naturalne skojarzyć można - z perspektywy typologii języków z tzw. klasami nominalnymi. Podział rzeczowników wg tej kategorii odznacza się większą regularnością semantyczną i morfologiczną, a jednocześnie większą szczegółowością niż podział na rodzaje (bo klas jest w danym języku zwykle kilkanaście). Oba jednak systemy są prymarnie syntaktyczne. Ponadto opozycja płci (czy także niedorosłości) nie jest dominująca w rozbudowanej semantyce klas nominalnych (zob. np. Bußmann 2002: 470; Mindak 1990: 16).

W językoznawstwie ogólnym istnieje też na tyle szerokie rozumienie rodzaju gramatycznego, że obejmuje swym zakresem również systemy klas nominalnych, np. z języka suahili (zob. STJ 1968: 489-490; Lyons 1976: 316-317). Semantycznym korelatem tak rozumianej kategorii rodzaju może być więc dowolny zespół wartości przedmiotu (np. kształt, konsystencja, jadalność czy kolor) (por. też Koziarski, Krysiak 2012).

${ }_{14}$ Por. Brzozowska 2005: 36: „Rodzaj naturalny związany jest z rzeczywistą płcią ludzi i zwierząt. Rodzaj gramatyczny natomiast jest kategorią arbitralną, która może się pokrywać z rodzajem naturalnym, ale nie musi 
A jednak rodzaj naturalny jako termin zdobywa się na autonomię, tyle że innego typu (by nie powiedzieć - rodzaju). Ujęcie takie znaleźć można w artykule Jana Mączyńskiego (1981: 234):

możliwość uzewnętrzniania pozajęzykowych cech [płci] przyjęto nazywać rodzajem naturalnym odpowiednich rzeczowników lub rodzajem referencjalnym.

Niepokoi w cytowanym fragmencie wskazanie rodzaju referencjalnego jako terminu równoważnego wobec rodzaju naturalnego. Mogłoby to bowiem oznaczać co najmniej zachwianie kategoryzacji semantycznej pojęcia na rzecz kategoryzacji pragmatycznej. Niereferencjalność znaczenia wskazuje się bowiem jako jeden z podstawowych wyróżników całej szeroko rozumianej semantyki strukturalistycznej (zob. Linde-Usiekniewicz 2008: 160). Jest jednak wątpliwe, że J. Mączyński świadomie wypisuje się z tej tradycji. Prawdopodobne używa więc określenia „referencjalny” nie w takim sensie, który stygmatyzuje pragmatyką, lecz takim, który zgodny jest m.in. z nurtem semantyki prawdziwościowej (por. Grzegorczykowa 2013: 12).

W świetle utożsamiania rodzaju naturalnego i referencjalnego w pragmatycznym rozumieniu tego słowa tym bardziej nie przekonywałaby - albo tym bardziej nie byłaby jasna - owa „możliwość” w sformułowaniu J. Mączyńskiego. Dlaczego tylko możliwość? ${ }^{15}$ Czy autor chciał powiedzieć, że rodzaj naturalny mieści w sobie również płeć nieujawnioną (nieznaną)? A może chciał tylko podkreślić, że istnieją różne środki wyrażania płci, ale jeśli tak, to czemu nie ujął tego wprost? W jego stylu mogłoby to brzmieć następująco: „rodzajem naturalnym nazywamy zbiór językowych technik uzewnętrzniania płci”.

Proponowana modyfikacja definicji nie niwelowałaby jednak rozbieżności poziomów abstrakcji między definiendum i genus proximum; w obu wypadkach - czyli zarówno definicji źródłowej, jak i zmodyfikowanej (rodzaj naturalny jako możliwość uzewnętrzniania i rodzaj naturalny jako zbiór technik) - rozbieżność ta wydaje się jeszcze większa od tej, która powstrzymuje przed kategoryzowaniem rodzaju naturalnego jako zgodności (nazwy rodzaju gramatycznego i cechy semantycznej). Nie znaczy to, że z gruntu odrzucamy takie szerokie (,abstrakcyjne”) spojrzenie na rodzaj naturalny.

To oczywiste, że rodzaj gramatyczny nie jest jedynym środkiem wyrażania płci. J. Mączyński (1981: 235-236) w sumie wyróżnia cztery ,sposoby (techniki) uzewnętrzniania rodzaju naturalnego": 1a) leksykalny syntetyczny (np. ojciec-matka), 1b) leksykalny analityczny (dyrektor - pani dyrektor, dyrektor Kowalska), 2a) gramatyczny syntetyczny (słowotwórczy ${ }^{16}$ ), 2b) gramatyczny analityczny (składniowy) (por. też Reczek 1975: 63).

Rodzajem naturalnym byłaby więc wyrażona różnymi środkami językowymi płeć denotatu/desygnatu (ewentualnie inna cecha znaczenia/referencji mająca pokrycie w rodzajowym nazewnictwie).

i często się nie pokrywa, zwłaszcza wtedy, gdy języki przypisują rodzaj gramatyczny obiektom pozbawionym płci naturalnej”.

15 Tłumacząc relację między semantyką a pragmatyką, Andrzej Bogusławski (2008) wykorzystuje porównanie do narzędzia i jego użycia. Pragmatyka nie zajmuje się możliwością użycia (,narzędziem”), lecz samym użyciem (,użyciem narzędzia”).

${ }^{16}$ Dla porządku należy odnotować, że słowotwórstwo też przekracza wymiar relacji między leksemami (tyle że są to leksemy formalnie i znaczeniowo pokrewne). 
Konsekwencją takiego podejścia jest mówienie o rodzajach naturalnych rzeczowników także w odniesieniu do języków (np. ugrofińskich), w których nie ma rodzajów gramatycznych (!). Powołując się na przykłady z języka węgierskiego, Tomasz Stefańczyk (2007: 21) pisze, że „rodzaj naturalny przybiera niekiedy bardziej precyzyjną postać w językach bezrodzajowych niż w posiadającej kategorię rodzaju gramatycznego polszczyźnie". Autor przyjmuje zatem koncepcję w pełni zautonomizowanego (wobec rodzaju gramatycznego) rodzaju naturalnego, który rozpatruje nie tylko na płaszczyźnie semantycznej, lecz także formalnej; jego zdaniem ma on bowiem pełnić „funkcję różnicowania rzeczowników, oznaczających istoty żywe, ze względu na ich płeć”. T. Stefańczyk nie zatrzymuje się jednak na rozróżnianiu płci, podany przez niego przykład (z języka węgierskiego) sygnalizuje także morfologiczne różnicowanie znaczeń w ramach jednej płci (takie, jak '(kobieta) król' i 'żona króla' ${ }^{17}$ ). W ujęciu autora pod szyldem rodzajów naturalnych (podobnie jak wcześniej u J. Mączyńskiego) chyba mieściłaby się zatem cała problematyka „naturalności” i precyzji środków językowych stosowanych odnośnie do płci.

Jeśli przedmiotem uwagi jest głównie intencja komunikacyjna, informacja (o płci), którą chcemy zakodować i nadać (a nie system języka), to rodzaj naturalny staje się prymarny wobec rodzaju gramatycznego (por. Reczek 1975: 63), a większego znaczenia - obok semantyki - nabiera perspektywa pragmatyczna.

W sumie wyróżnimy cztery podstawowe typy objaśniania rodzaju naturalnego. Trzy z nich można przedstawić za pomocą następującego schematu.

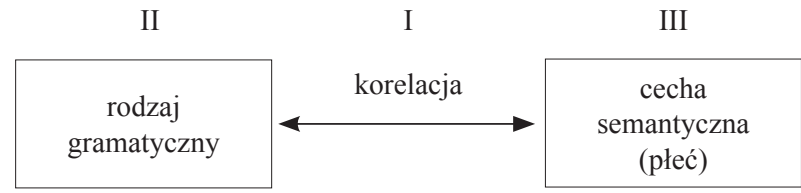

Denotacje definicji z tych trzech typów (bo i typ I ma przecież swoje - choć nieklasyczne - definicje, por. te przytoczone na początku z Saloniego) nie mogą być jednakowe - wszak czym innym jest rodzaj gramatyczny, czym innym semantyczna cecha płci, a jeszcze czym innym ich korelacja czy zgodność (i tak zresztą nietraktowana jako genus proximum rodzaju naturalnego). Dopóki jednak definicje ograniczają się do - niekwestionowanego chyba ${ }^{18}$ - prototypu czy jądra pojęcia: masculina o znaczeniu męskim i feminina o znaczeniu żeńskim (ewentualnie z rozszerzeniem na neutra o znaczeniu niedorosłym), różnice między nimi wydają się bardziej kwestią odmiennej stylizacji czy profilowania (by nie powiedzieć przesadnej akademickiej pedanterii) niż merytorycznych rozbieżności. Konsekwencje wyboru sposobu rozumienia rodzaju naturalnego ujawniają się dopiero wtedy, gdy analizujemy (inne jeszcze niż tylko uwzględnianie nijakiego/,„niedorosłego” rodzaju naturalnego) możliwości rozszerzenia tego pojęcia, wyjścia poza wspólny prototyp. Ogólnie należy stwierdzić, że w wypadku traktowania rodzaju naturalnego jako cechy semantycznej te możliwości sięgają najdalej, z kolei nacisk na cechę zgodności zasadniczo

17 Łączenie obu tych znaczeń przez polski rzeczownik KRÓLOWA podkreślają Mirosław Koziarski i Adrian P. Krysiak (2012: 33).

18 Nie słyszeliśmy bowiem, aby ktoś ze zwolenników szerokiego rozumienia rodzaju naturalnego (od strony semantycznej), ,wychylał się” z jakimś niezgodnościowym kontrprototypem rodzaju naturalnego. 
je ogranicza. Szersze pojęcie korelacji (por. drugą z cytowanych na początku definicji Zygmunta Saloniego (1976: 50) ) zdaje się już wprawdzie otwierać większe możliwości (jeśli nie określimy, o jaki typ korelacji chodzi, nie sprowadzimy jej do zgodności), ale tym samym prowadzi właśnie do niepożądanych komplikacji, które wolimy z góry odrzucić.

Ostatni - czwarty - typ objaśniania rodzaju naturalnego jest trochę ,z innej bajki” i nie mieliśmy pomysłu, jak go ująć na jednym schemacie z pozostałymi. Wedle tej koncepcji - wywiedzionej z pracy J. Mączyńskiego, a także T. Stefańczyka - rodzaj naturalny może, ale nie musi być rodzajem gramatycznym, rozpatrywanym oczywiście pod kątem wyrażania płci. Co ciekawe, mimo swej pojemności i ta koncepcja zdaje się respektować prototyp zgodności rodzaju gramatycznego z płcią (z paradoksalnym zastrzeżeniem - o ile rodzaj gramatyczny istnieje w danym języku!). Nie uznaje ona jednak rodzaju gramatycznego za hiperonim naturalnego, lecz to właśnie rodzaj naturalny czyni pojęciem nadrzędnym choć bardziej już typu kolektywnego niż hiperonimicznego - zarówno wobec rodzaju gramatycznego, jak i wobec cechy semantycznej. T. Stefańczyk posuwa się dalej i stosuje pojęcie rodzaju naturalnego do języków bezrodzajowych. Zbiór technik wyrażania płci nie musi być bowiem jednakowy dla wszystkich języków i rodzaj gramatyczny - choć uprzywilejowany - nie jest techniką niezbędną.

\section{Rozszerzenia rodzaju naturalnego}

Dostrzegamy pięć typów możliwych rozszerzeń pojęcia rodzaju naturalnego, pięć kierunków wychodzenia poza jego prototyp:

1. wyróżnianie nijakiego rodzaju naturalnego (rozszerzenie najbliższe prototypowi);

2. przypisywanie rodzaju naturalnego rzeczownikom o niejednolitej semantyce płci (która nie może być sprowadzona do etykiety „męski” lub ,żeński”);

3. uznawanie rodzaju naturalnego niezgodnego z rodzajem gramatycznym;

4. „rozliczanie” z rodzaju naturalnego wszystkich rzeczowników będących nazwami istot płciowych;

5. wyróżnianie podrodzajów naturalnych masculinów (rodzajów naturalnych drugiego stopnia).

Rozszerzenia 1. i (jeszcze bardziej) 5. osłabiają fundamentalny związek rodzaju naturalnego z semantyczną cechą płci. Z kolei rozszerzenie 2. opiera się na relatywizacji dwóch przeciwstawnych wartości tej cechy. W odniesieniu do rzeczowników o niejednolitej semantyce płci siłą rzeczy nie może zachodzić pełna zgodność między rodzajem gramatycznym i znaczeniem, trzeba zejść na poziom referencji. Samo przeciwstawianie ogólnego (semantycznego) i szczegółowego (referencjalnego) wymiaru rodzaju naturalnego stanowi już komplikację, która odbiega od klarownego „zgodnościowego” prototypu pojęcia. Rozszerzenie 3. możliwe jest wyłącznie wtedy, gdy traktujemy rodzaj naturalny jako cechę semantyczną (definicja typu III na schemacie). Rozszerzenia 4. i 5. poza pracą Wojdaka (2013) nie były chyba dotąd sygnalizowane w literaturze; inna sprawa, że rozszerzenie 4. jest bodaj najbardziej podatne na nieeksplicytność (niejawność), ,pozaludzki” zakres pojęcia rodzaju naturalnego - mimo niewątpliwie uprzywilejowanej pod względem językowym pozycji zwierząt hodowlanych - nie jest wytyczany w sposób wyraźny. 
Skoro uwzględniamy tak różne i daleko idące możliwości rozszerzenia pojęcia rodzaju naturalnego, to wypada także wspomnieć o perspektywie nie tyle już kolejnego kierunku tego rozszerzenia, co wręcz nowego znaczenia rodzaju naturalnego, wynikającego z rozliczania rodzaju gramatycznego z innego niż wyrażanie płci wymiaru naturalności - z wymiaru morfologicznego (inspiruje do tego opis rodzaju naturalnego i gramatycznego u S. Szobera, por. przypis 7.). Nie optujemy bynajmniej za jakimś wyemancypowanym wobec rodzaju gramatycznego „rodzajem morfologicznym”; chcemy tylko stwierdzać, czy rodzaj gramatyczny danego rzeczownika jest czy nie jest (ewentualnie w jakim stopniu jest) naturalny pod względem morfologicznym (czy jego wykładniki są czy nie są naturalne). Byłoby to zatem dodatkowe spojrzenie na naturalność w ramach orientacji gramatycznej - potrzebne i przecież z powodzeniem już od (dawien) dawna praktykowane w opisie relacji między rodzajami gramatycznymi i końcówkami, tyle że z zastosowaniem różnej terminologii (niekoniecznie z ,rodzajem naturalnym”).

\subsection{Rodzaj naturalny nijaki}

Pojęcie rodzaju naturalnego niezależnie od sposobu jego kategoryzacji może być dopełnione trzecim - po rodzaju męskim i żeńskim - członem podstawowej triady rodzajowej, który wcale nie ma nazwy „płciowej”. Naturalny rodzaj nijaki przypisuje się neutrom nazywającym istoty niedorosłe bez określania ich płci, czyli takim jak DZIECKO, ale już nie takim jak CHŁOPIEC i DZIEWCZYNA (Kucała 1978: 137, Miko 1962: 57 za Zieniukowa 1981: 12). Czynnik płci - konstytutywny dla problematyki rodzajów naturalnych - ma bowiem wyższą rangę niż czynnik niedorosłości, a obu tych czynników nie da się pogodzić jednym rodzajem gramatycznym (rodzaj gramatyczny musi być jeden, a cechy semantyczne są dwie); w przypadku CHEOPCA i DZIEWCZYNY nie ma więc sytuacji prototypowej dla rodzaju naturalnego. Tylko na gruncie semantycznego rozumienia rodzaju naturalnego można by operować jego wartościami złożonymi: męskim niedorosłym (CHEOPIEC) i żeńskim niedorosłym (DZIEWCZYNA) (por. punkt 2.3.).

\subsection{Rzeczowniki o niejednolitej semantyce płci}

Odnoszenie rodzaju naturalnego do rzeczowników osobowych (żywotnych) o niejednolitej semantyce płci (np. GAPA, OSOBA, RODZICE) ${ }^{19}$, a przy tym nienacechowanych niedorosłością ma dwie konsekwencje. Prowadzi, po pierwsze, do wyróżniania dodatkowych wartości rodzajów naturalnych, które nie mają odpowiedników w rodzajach gramatycznych

19 Barbara Batko-Tokarz (2013) nazywa takie jednostki rzeczownikami niejednoznacznymi ze względu na płeć, a Magdalena Horodeńska-Ostaszewska - przyjmując, że „,warunkiem uznania określenia płci za element znaczenia leksemu jest stosowanie go tylko do tej płci" (2011: 212-213) - zalicza je do nazw nieinformujących o płci (por. Batko-Tokarz 2013: 78). Rzeczownikami o nieokreślonej semantyce płci skłonni jesteśmy nazywać tylko te, które odnoszą się od obydwu płci bez wyraźnych różnic w nacechowaniu pragmatycznym. Wiąże się to $\mathrm{z}$ faktem, że dana jednostka nie ma morfologicznie pokrewnego przeciwczłonu o płci określonej. Takie warunki spełnia np. OSOBA, ale nie GAPA F. Rzeczowniki o nieokreślonej semantyce płci stanowiłyby więc podgrupę rzeczowników o niejednolitej semantyce płci. 
(zob. niżej ad 1), po drugie, do rozpatrywania rodzaju naturalnego osobno na płaszczyźnie semantyki (denotacji) i osobno na płaszczyźnie referencji (różnie pod względem płci konkretyzowanego odniesienia) (zob. ad 2).

Ad 1: Liczba rodzajów naturalnych rozumianych jako typy semantyki płci rzeczowników jest kwestią otwartą. We wcześniejszych publikacjach (Wojdak 2005: 354-355; 2013: 70-71) wymienialiśmy wymieniał następujące wartości:

- mieszany - nazwy zbiorów płciowo mieszanych (większość męskoosobowych pluraliów tantum, np. PAŃSTWO, RODZICE)

- niedookreślony z przewagą męskiego - nazwy gatunkowe opozycyjne wobec nazw żeńskich, gramatycznie męskie (np. DYREKTOR MI, PIES)

- niedookreślony z przewagą żeńskiego - nazwy gatunkowe opozycyjne wobec nazw męskich, gramatycznie żeńskie (np. GWIAZDA 'osoba', KACZKA, KURA, PSZCZOモA)

- nieokreślony - nazwy ludzi i zwierząt neutralne pod względem płci i nienacechowane niedorosłością (np. PTAK, OSOBA, ZWIERZE, DZIECKO w znaczeniu 'człowiek w relacji do swoich rodziców')

Jak wspomnieliśmy w punkcie 2.1., z zakresu rodzajów podstawowych: męskiego i żeńskiego, w duchu prezentowanego rozszerzenia uzasadnione byłoby także wyodrębnienie rodzajów złożonych z komponentem „niedorosłym”: męski niedorosły (CHŁOPIEC) i żeński niedorosły (DZIEWCZYNA). Ze względu na biologiczny typ organizmów (naturalny lub dewiacyjny) można jeszcze dodać rodzaj obojnaczy (TASIEMIEC), który jednak prowadziłby do rozszerzenia pojęcia także w ramach czwartego z wyróżnionych typów (por. dalej podpunkt 2.4.).

Ad 2: Zgodność rodzaju gramatycznego z płcią jest albo stałą (słownikową) cechą leksemów rzeczownikowych, albo - jak właśnie w wypadku jednostek o niejednolitej semantyce płci - tylko ich cechą tekstową (cechą użycia/referencji).

Gdy płeć osobnika nazywanego takim rzeczownikiem pozostaje nieznana, rodzaj naturalny nie podlega weryfikacji. Rodzaj referencjalny odznacza się zatem kognitywną względnością. Zwracaliśmy już uwagę, że w definicji J. Mączyńskiego takie właśnie wyrażenie („rodzaj referencjalny”) pojawia się jako termin zamienny wobec „rodzaju naturalnego", co mogłoby oznaczać, że pojęcie prymarnie lokalizowane jest na płaszczyźnie pragmatyki, a nie semantyki. Jak długo obracamy się w kręgu masculinów o znaczeniu męskim i femininów o znaczeniu żeńskim, kwestia prymatu jednej bądź drugiej płaszczyzny nie wydaje się istotna (rzecz ma się więc podobnie, jak z alternatywą ujmowania rodzaju naturalnego albo od strony gramatycznej, albo semantycznej) ${ }^{20}$. Jej ranga wzrasta dopiero w odniesieniu do rzeczowników o niejednolitej semantyce płci. Orientacja pragmatyczna niewątpliwie sprzyja rozliczaniu tych jednostek z rodzaju naturalnego, ale powstaje pytanie, jak daleko powinno sięgać to rozliczanie (KIJANKA tylko w odniesieniu do samicy będzie miała ,zgodny” rodzaj naturalny, a w odniesieniu do samca - nie; w sumie zaś rzeczownik ten jest znaczeniowo niedorosły i nieokreślony pod względem płci).

20 Trzeba jednak przyznać, że również rzeczowniki osobowe o oczywistej - wydawałoby się - semantyce jednopłciowej dostarczyć mogą przykładów użycia, które wskazują na potrzebę rozróżniania dwóch wymiarów rodzaju naturalnego - semantycznego i referencjalnego, np. w sytuacji, gdy kobieta przebrana jest za mężczyznę, możemy powiedzieć: dwoje chłopców, szwagrów, wdowców itd. 
Przy i tak szerokim podejściu do rodzajów naturalnych kwestię stosunku semantyka pragmatyka można rozwiązywać „,polubownie” (por. sformułowane na koniec punktu 2. maksymalistyczne - niegramatyczne - ujęcie rodzaju naturalnego).

\subsection{Rodzaj naturalny niezależny od rodzaju gramatycznego}

Wszędzie tam, gdzie mowa jest o korelacjach między rodzajem gramatycznym i rodzajem naturalnym (por. np. Nowosad-Bakalarczyk 2009: 18-21, Laskowski 1998: 208), a więc gdzie rodzaj naturalny przeciwstawiany jest rodzajowi gramatycznemu, chodzi o inaczej jeszcze rozszerzone (odgramatykalizowane) ujęcie rodzaju naturalnego, które prowadzi do utożsamiania go z płcią (ewentualnie inną cechą semantyczną) niezależnie już od wartości rodzaju gramatycznego.

Zgodnie z tym rozszerzeniem nie powiemy, że CHŁOPISKO $N$ i BABSZTYL nie mają rodzaju naturalnego, lecz że mają rodzaj naturalny (odpowiednio: męski i żeński) niezgodny z rodzajem gramatycznym (odpowiednio: nijakim i męskim, a dokładniej męskozwierzęcym). Nie tylko DZIECKO, CIELE, ŹREBIE, ale także DZIECIAK, CIELAK, ŹREBAK miałyby rodzaj naturalny nijaki.

\section{4. „Rozliczanie” $\mathrm{z}$ rodzaju naturalnego wszystkich rzeczowników będących nazwa- mi istot płciowych}

Problematyka rodzajów naturalnych pozbawiona perspektywy antropocentrycznej (a także ram słownictwa ogólnego przeciwstawianego naukowym terminologiom) rozmywa się na rzecz fachowej wiedzy biologicznej, wiedzy o sposobach rozmnażania i formach płciowości. Możemy się zapytać, co nas językoznawców obchodzi płciowość (rozdzielnopłciowość albo obupłciowość/hermafrodytyzm) czy bezpłciowość dżdżownicy, tasiemca, ukwiału i - ogólnie - roślin, grzybów, bakterii. I co my o tym wiemy?

Większość roślin wyższych (naczyniowych: paprotników i nasiennych) odznacza się obupłciowością. W świecie zwierząt dominuje rozdzielnopłciowość (powszechna jest u kręgowców), brakiem zróżnicowania płciowego (obojnactwem) wyróżnia się m.in. większość płazińców i wiele pierścienic (por. NEP PWN 4: 922; 5: 608). Lecz zakres i rodzaje płciowości organizmów nie są przecież fachowym zagadnieniem gramatyki!

Ponadto pod względem samego tylko zoologicznego zakresu orzekania rodzaju naturalnego jako konieczne mogłoby się wydawać uznanie stopniowalności przynależności do pojęcia. Im zwierzę bardziej znane i bliskie człowiekowi i im jego nazwa bardziej rozpowszechniona (w języku niespecjalistycznym), tym pewniejsze rozliczanie tej nazwy z rodzaju naturalnego.

Lansowanie w językoznawstwie hermafrodytyzmu i bezpłciowości byłoby sztuczne i niewygodne, a sankcjonowanie stopniowalności kategoryzacyjnej bez ustalenia kanonu cech definicyjnych byłoby z kolei nieścisłe. Jeśli nie godzimy się na zoologicznie maksymalistyczne ujęcie rodzaju naturalnego, możemy eksplikować warunek, zgodnie z którym o rodzaju naturalnym mówimy wtedy, gdy dla danego gatunku organizmów oprócz nazwy ogólnej istnieje choćby jedna nazwa wyróżniająca którąś z płci. Jeśli mamy w języku tylko 
nazwę ogólną (nienacechowaną pod względem płci), to nie może być mowy o rodzaju naturalnym, nawet $\mathrm{w}$ świetle najbardziej pojemnej definicji tego pojęcia (przewidującej jego wartość nieokreśloną). Oznacza to, że poza zakresem pojęcia znalazłyby się również nazwy gatunków obojnaczych (np. TASIEMIEC). Wartość obojnaczą rodzaju naturalnego i tak należałoby jednak zachować ze względu na odniesienia nazw osobowych i zwierzęcych do osobników o obojnactwie dewiacyjnym - poza samymi rzeczownikami OBOJNAK i HERMAFRODYTA byłby to więc rodzaj naturalny funkcjonujący w wymiarze tylko referencjalnym (a nie semantycznym).

Z podobnym ograniczeniem można wystąpić w kwestii związanej ze współistnieniem nazw ogólnych i nazw istot niedorosłych (w różnych stadiach rozwojowych, np. ŻABA a $K I-$ JANKA) przy braku nazw wyróżniających którąś z płci. Zgodnie z „ciążeniem” prototypu takie rozróżnienie nie byłoby wystarczającą podstawą do orzekania rodzajów naturalnych (nieokreślonego i niedorosłego).

\subsection{Podrodzaje naturalne masculinów (rodzaje naturalne drugiego stopnia?)}

Jeśli rodzaje naturalne motywowane są nazwami rodzajów gramatycznych (wskazującymi na ich prototyp znaczeniowy), to musimy jeszcze rozpatrzyć kwestię wyjścia poza podstawową triadę rodzajową (masulinum - femininum - neutrum) na rzecz dodatkowego rozróżniania trzech (pod)rodzajów naturalnych masculinów

To rozszerzenie wydaje się poniekąd uprzywilejowane z gramatykocentrycznej perspektywy rozumienia rodzaju naturalnego (typ II na schemacie), skoro w gramatyce akademickiej rozróżnia się pięć podstawowych rodzajów gramatycznych rzeczownika (na podstawie łączliwości form biernika), w tym trzy męskie (zob. m.in. Laskowski 1998: 208-213). Trudność z klasyfikacją rodzajów naturalnych, która miałaby odpowiadać tej klasyfikacji pięciorodzajowej, polega jednak na tym, że nie może być ona ujmowana jako jedna pięcioczłonowa opozycja, lecz jako dwie opozycje niezależne, bo zakres drugiej wcale nie stanowi podzakresu pierwszej. Przykładowo STÓ i PAPIEROS jako rzeczowniki nieżywotne nie są rozpatrywane ze względu na triadę podstawowych rodzajów naturalnych, ale pierwszy ma naturalny podrodzaj męski (męskonieżywotny/męskorzeczowy), o drugim można powiedzieć, że ma podrodzaj męski (męskozwierzęcy) nienaturalny (por. dalej punkt 3.).

Przed operowaniem „od razu” pięcioma wartościami podstawowymi rodzaju naturalnego powstrzymuje asymetria między podzieloną „męskością” i niepodzielną ,żeńskością”; ale nawet niezależnie od tej asymetrii dobrze byłoby w czystej postaci zachować nadrzędność tradycyjnej - tylko płciowej - opozycji. Inna sprawa, że opozycję tę i tak zaburzają męskoosobowe pluralia tantum, które w ogromnej większości mają znaczenie osobowe (sygnalizowany już dawno w literaturze wyjątek to SATELITA w znaczeniu 'państwo satelickie’, zob. Bogusławski 1976, za: Rothstein 1976: 247), więc powinny być rozliczane z naturalności rodzaju ${ }^{21}$.

${ }^{21}$ Przy okazji chcemy sprostować nieścisłość, która pojawiła się w monografii o wielorodzajowości (Wojdak 2013) przy prezentowaniu relacji między rodzajami gramatycznymi i naturalnymi. W tabeli 4 . na s. 71 w kolumnie dla gramatycznego rodzaju męskiego znalazły się oto również przykłady męskoosobowych pluraliów tantum; w tekście pod tabelą fakt ten został wprawdzie odnotowany (,pod rodzaj męski podciągnięto także męskoosobowe pluralia tantum”), ale bez żadnego uzasadnienia. Tymczasem takie ,podciągnięcie” należy uznać 
Schodząc z poziomu podstawowej triady rodzajowej na poziom opozycji wewnątrzmęskich, w większym stopniu doświadczamy innej jeszcze trudności: wspomnianej już na początku skazy nazewniczego relatywizmu rodzajów naturalnych. Za pomocą etykiet rodzajowych można bowiem różnie „wyważać” czy „ustawiać” rodzaje naturalne, por. rodzaj męskozwierzęcy a rodzaj męskożywotny nieosobowy, rodzaj męskonieżywotny a rodzaj męskorzeczowy. Podział na (pod)rodzaje naturalne objąłby wszystkie masculina, gdyby stosowany był według etykiet/kryteriów: „osobowość”, ,żywotność nieosobowa” i „nieżywotność" (ta ostatnia rozumiana jako cecha dopełniająca semantyczne uniwersum w stosunku do dwóch wcześniej wymienionych). Aby zachować jednak większe podobieństwo wobec dalekiego od uniwersalności podstawowego podziału na rodzaje naturalne, za cechę konstytutywną drugiego rodzaju lepiej uznać „zwierzęcość”, a trzeci rodzaj chyba zawęzić do „rzeczowości” - wtedy z podrodzaju naturalnego nie byłyby rozliczane nie tylko nazwy innych organizmów niż ludzie i zwierzęta (a więc nazwy roślin, grzybów, bakterii, problematycznych biologicznie wirusów), ale także wszystkie rzeczowniki abstrakcyjne.

Usankcjonowanie podrodzajów naturalnych rzeczowników męskich miałoby zaletę dydaktyczną - uczulałoby na to, żeby nie utożsamiać trzech gramatycznych rodzajów męskich z odpowiednimi klasami semantycznymi masculinów (według cech odpowiadających etykietom rodzajowym).

W najszerszym ujęciu rodzaj naturalny przysługiwałby wszystkim nazwom osób i zwierząt (rzeczownikom żywotnym) jako charakterystyka płci, niedorosłości (korelatu gramatycznej nijakości/neutralności) lub innych jeszcze etykietalnych cech rodzajowych należąca do ich znaczenia leksykalnego i konkretyzowana w poszczególnych użyciach.

\section{Rodzaj/podrodzaj nienaturalny jako alternatywa dla szerokiego rozumienia rodzaju naturalnego}

Tym, co niepokoi w orzecznictwie gramatycznie rozumianych rodzajów naturalnych, a co wiąże się z ograniczonością sfery ich działania, jest brak rozróżnienia wartości negatywnych, tzn. przykładowo o rzeczownikach BABSZTYL i KSIĄŻKA mówi się jednakowo, że nie mają rodzaju naturalnego. Ale BABSZTYLA (jako nazwę osobową) z rodzaju naturalnego rozliczać można, a KSIĄŻKI - nie. Można powiedzieć, że BABSZTYL ma rodzaj opozycyjny do rodzaju naturalnego, a więc rodzaj nienaturalny (antynaturalny?).

Jeśli zdecydujemy się na takie - czytelne i sugestywne - określenie („,nienaturalny”) w odniesieniu do trzech rodzajów podstawowych, to możemy je również stosować do opisu podrodzajów w obrębie masculinów. Przykładowo podrodzaj nienaturalny - zwierzęcy

za błąd logiczny. Rodzaj męski nie jest bowiem hiperonimem w stosunku do tego tzw. rodzaju męskoosobowego przymnogiego. Nagłówek kolumny należało więc raczej uszczegółowić: „rodzaj męski (i męskoosobowy pluraliów tantum)".

Męskoosobowe pluralia tantum nie pasują do „rodziny męskiej”, ale paradoksalnie jednoznacznie pasują na tyle, na ile istnieją - do rodzaju męskoosobowego rzeczowników niedefektywnych. Pod tym względem nie konstytuują osobnej podstawowej wartości rodzajowej. 
zamiast „oczekiwanego” na podstawie znaczenia nieżywotnego (rzeczowego) - mają takie masculina, jak WALC, MERCEDES czy wspomniany już PAPIEROS.

O nienaturalności (nie tylko o naturalności) rodzaju gramatycznego można też mówić, rozpatrując jego charakterystykę morfologiczną (np. rodzaj gramatyczny nienaturalny pod względem morfologicznym w lp. mają rzeczowniki typu POETA).

\section{Wnioski}

Popieramy wąską - gramatyczną, a nie semantyczną (tym bardziej nie pragmatyczną - kategoryzację rodzaju naturalnego. Oprócz wartości męskiej i żeńskiej uwzględniamy wartość nijaką, która przysługuje neutrom nazywającym istoty niedorosłe o nieokreślonej płci (naturalny rodzaj nijaki lub „niedorosły”). Jako termin ogólny promujemy: „naturalny rodzaj gramatyczny".

Ograniczenia w orzekaniu naturalnych rodzajów gramatycznych (męskiego i żeńskiego) niech paradoksalnie będą rekompensowane antonimicznym pojęciem nienaturalnego rodzaju gramatycznego, stosowanym w odniesieniu do rzeczowników o jednolitej semantyce płci, które nie mają naturalnego rodzaju gramatycznego, ale mogą być z niego $-\mathrm{z}$ racji znaczenia osobowego - rozliczane (CHŁOPISKO N, BABSKO, BABSZTYL).

Akceptujemy też niemające kształtu definicji klasycznych „,neutralne” objaśnienia rodzaju naturalnego, które mówią o zgodności czy korelacji między rodzajem gramatycznym i cechą semantyczną (jednoznacznie określoną płcią). W duchu prostoty nie dopuszczalibyśmy tu jednak korelacji rozumianych inaczej niż zgodność - polegających na zgodności tylko częściowej (w zmiennym wymiarze referencjalnym).

Jednocześnie popieramy zwyczaj mówienia o różnych (ko)relacjach między rodzajem gramatycznym a znaczeniem (w tym oczywiście cechą płci) bez stosowania terminu rodzaj naturalny (w szerokim rozumieniu).

Upominamy się o dokładniejsze niż do tej pory eksplikacje pojęcia rodzaju naturalnego: szczególnie w słownikach językoznawczych, ale także w gramatykach, monografiach i studiach - jeśli tylko ich autorzy używają terminu rodzaj naturalny. Życzymy sobie przede wszystkim, aby na zawsze zniknęły pokrętne tłumaczenia, z których wynika bez mała, że rodzaj naturalny jest i nie jest rodzajem gramatycznym.

Nie należy z góry przekreślać niegramatycznych ujęć rodzaju naturalnego - ważna jest jednak właśnie ich eksplicytność: jasne deklaracje co do zakresu, kanonu uznawalnych wartości semantycznych (czy tylko męskość i żeńskość czy jeszcze coś więcej?), no i tym bardziej - co do podstawowej perspektywy rozumienia pojęcia; doskwiera tymczasem brak refleksji nad stosunkiem między semantyką i pragmatyką.

\section{Bibliografia}

Bańczerowski J., Pogonowski J., Zgółka T., 1982, Wstęp do językoznawstwa. Skrypt dla studentów studiów uniwersyteckich, Poznań.

Bańko M., 2002, Wykłady z polskiej fleksji, Warszawa.

Batko-Tokarz B., 2013, O różnorodnych definicjach słownikowych rzeczowników męskoosobowych, „Poradnik Językowy”, z. 10, s. 71-86. 
Bąk P., 1984, Gramatyka języka polskiego, Warszawa (wyd. 4).

Bogusławski A., 1976, Segmenty, operacje, kategoryzacja a morfologia imienia polskiego, w: Kategorie gramatyczne grup imiennych w języku polskim, red. R. Laskowski, Wrocław, s. 7-42.

Bogusławski A., 2008, Semantyka, pragmatyka. Leksykografa głos demarkacyjny, Warszawa.

Brzozowska D., 2005, Kategoria rodzaju we współczesnym języku polskim, „Język Polski” LXXXV, s. $36-42$

Bußmann H., 2002, Lexikon der Sprachwissenschaft. Dritte, aktualisierte und erweiterte Auflage, Stuttgart.

EJO - Encyklopedia językoznawstwa ogólnego, red. K. Polański, Wrocław 1999 (wyd. 2).

EJP - Encyklopedia języka polskiego, red. S. Urbańczyk, M. Kucała, Wrocław 1999 (wyd. 3).

Grochola-Szczepanek H., 2010, Korelacja rodzaju gramatycznego i naturalnego $w$ dialektach polskich, „Jezikoslovni zapiski” 16/2, s. 157-164.

Grzegorczykowa R., 2013, O różnych rozumieniach pragmatyki w językoznawstwie, „Biuletyn PTJ” LXIX, s. 5-22.

Horodeńska-Ostaszewska M., 2011, O nazwach osób. Problemy z symetrycznościa informacji o ptci, w: Osoby i działania. Wokót Stownika nazw osobowych, red. Z. Zaron, S. Dubisz, s. 207-306.

Język polski. Kompendium, red. H. Derwojedowa, H. Karaś, D. Kopcińska, Warszawa 2005.

Judycka I. i inni, 1971, Polska terminologia składniowa, w: Problemy składni polskiej. Studia, dyskusje, polemiki z lat 1945-1970, wybrał, ułożył i wstępem opatrzył A.M. Lewicki, Kraków, s. 220-233.

Karpowicz T., 1999, Gramatyka języka polskiego, Warszawa.

Klemensiewicz Z., 1986, Podstawowe wiadomości z gramatyki języka polskiego, Warszawa (wyd. 14).

Kowalikowa J., 2005, abc wiedzy o języku polskim (dla maturzysty, kandydata na studia i każdego, kto lubi wiedzieć), Kraków (wyd. 2).

Koziarski M., Krysiak A.P., 2012, Rodzaj gramatyczny rzeczownika jako nośnik informacji pozagramatycznej I. Przeglad literatury dotyczacej rodzaju gramatycznego, „Investigationes Linguisticae" XXVI, s. 20-38 [http://www.staff.amu.edu.pl/ inveling/pdf/Koziarski-26.pdf].

Kucała M., 1978, Zmiany semantycznych podstaw rodzaju gramatycznego, w: Z polskich studiów slawistycznych. Seria 5. Językoznawstwo, Warszawa, s. 137-150.

Laskowski R. 1998 - zob. Morfologia.

Linde-Usiekniewicz J., 2008, Semantyka strukturalna w XXI wieku? w: Metodologie językoznawstwa. Współczesne tendencje i kontrowersje, red. P. Stalmaszczyk, Kraków, s. 158-173.

Lyons J., 1976, Wstęp do językoznawstwa, Warszawa.

Mayenowa M.R., 1974, Poetyka teoretyczna. Zagadnienia języka, Wrocław.

Mączyński J., 1981, Opozycje semantyczne rzeczowników oznaczających osoby we wspótczesnym języku Polskim, „Acta Universitatis Lodziensis, Folia Linguistica” 2, s. 233-242.

Mindak J., 1990, Językowa kategoria żywotności w polszczyźnie i słowiańszczyźnie na tle innych języków świata. Próba ujęcia typologicznego, Wrocław.

Miko F., 1962, Rod, čislo a pád podstatnych mien, Bratysława.

Morfologia. Gramatyka wspótczesnego języka polskiego, t. 2, red. R. Grzegorczykowa, R. Laskowski, H. Wróbel, Warszawa 1984, wyd. II (zmienione) 1998.

Nagórko A., 1997, Zarys gramatyki polskiej, Warszawa.

NEP PWN - Nowa encyklopedia powszechna PWN, t. 1-7, Warszawa 1995.

Nowosad-Bakalarczyk M., 2009, Płeć a rodzaj gramatyczny we współczesnej polszczyźnie, Lublin.

Płóciennik I., Podlaska D., 2007, Słownik wiedzy o języku, Bielsko-Biała (wyd. 5).

Polański E., Nowak T., 2011, Najnowszy podręcznik gramatyki języka polskiego, Kraków.

Przepiórkowski A. i in., 2002, Formalny opis języka polskiego. Teoria i implementacja, Warszawa.

Reczek J., 1975, recenzja książki: Kenneth L. Nalibow, Genus versus Sexus. Professional Titles, Working Titles and Surnames for Women in Contemporary Standard Polish, "European Univer- 
sity Papers”, series XVI: Slavonic languages and literatures, vol. 2. Herbert Lang, Bern, Peter Lang, Frankfurt/M. 1973, s. 139 + 1nlb., „Język Polski” LV, s. 61-67.

Rothstein R., 1976, Uwagi o rodzaju gramatycznym i cechach semantycznych wyrazów, „Język Polski" VLI, s. 241-253.

Saloni Z., 1976, Kategoria rodzaju we współczesnym języki polskim, w: Kategorie gramatyczne grup imiennych. Materiały konferencji w Zawoi 13-15 XII 1974, red. R. Laskowski, Wrocław, s. 43-78 oraz 87-106 [dyskusja nad referatem].

Słownik gramatyki języka polskiego, red. J. Bralczyk, W. Gruszczyński, Warszawa 2002.

Stefańczyk T., 2007, Kategoria rodzaju i przypadka polskiego rzeczownika, Kraków.

STJ - S. Gołąb, A. Heinz, K. Polański, Stownik terminologii językoznawczej, Warszawa 1968.

Strutyński J., 1997, Gramatyka polska (wydanie nowe rozszerzone), Kraków.

Szober S., 1953, Gramatyka języka polskiego, opracował W. Doroszewski. Warszawa (wyd. 3.).

Tokarski J., 1967, Z pogranicza metodyki i jezzkoznawstwa, Warszawa.

Weiss D., 1993, How many sexes are there? (reflections on natural and grammatical gender in contemporary Polish and Russian), w: Studies in Polish Morphology and Syntax, edited by G. Hentschel, R. Laskowski, München 1993, s. 71-105.

Wojdak P., 2005, Problemy opisu polskiej fleksji (Uwagi do i wokół „, Wykładów...” M. Bańki), „Polonica" XXIV-XXV, s. 349-368.

Wojdak P., 2013, Wielorodzajowość wśród rzeczowników współczesnej polszczyzny, Szczecin

Wróbel H., 2001, Gramatyka języka polskiego, Kraków.

Zieniukowa J., 1981, Rodzaj męski osobowy we współczesnych językach zachodniosłowiańskich, Wrocław.

\section{PIOTR WOJDAK}

\section{What is (in-) natural gender and what is its scope?}

\section{Summary}

The article presents considerations concerning the essence and the scope of the concept of the natural gender of nouns. The author advocates its grammatical categorisation - instead of the semantic categorisation dominating in the literature. This means that the superior category in natural gender should be grammatical gender (hence the proposed compound term: natural grammatical gender), and not a semantic feature. In a simple (prototypical) categorisation, natural gender pertains to masculine nouns with male meaning and feminine nouns with female meaning. The article identifies five types of possible extension of this concept:

1. the isolation of the neuter natural gender;

2. the attribution of natural gender to nouns with inconsistent semantics of sex;

3. the recognition of the natural gender which is incompatible with grammatical gender (this extension is only possible when natural gender is treated as a semantic feature);

4. the analysis of all nouns that denote sexual beings with regard to natural gender;

5. the isolation of subcategories of natural masculine nouns (natural genders of the second degree).

Complimentary to the narrow understanding of natural gender, the author proposes to use an antonymous term - "unnatural gender" to designate such kind of grammatical gender of personal (or animate) nouns that is not in compliance with their semantic feature of sex (e.g., CHŁOPISKO [A CHAP], BABSZTYL [A HAG]).

Keywords: linguistics, grammatical gender, natural gender 
